\title{
Tide-driven deep pore-water flow in intertidal sand flats
}

\author{
Hans Røy, ${ }^{1}$ Jae Seong Lee, ${ }^{2}$ Stefan Jansen, ${ }^{3}$ and Dirk de Beer \\ Max-Planck-Institute for Marine Microbiology, Celsiusstrasse 1, D-28359 Bremen, Germany
}

\begin{abstract}
Sulfidic seeps with methane ebullition were observed at the low-water line of intertidal sand flats at a number of locations in the Wadden Sea. Bioturbating fauna was absent in the seep areas but abundant in the more central areas of the tidal flat. At one site, the vertical methane and sulfate distribution in pore water was determined along transects from the low-water line toward the interior of the sand flat. The resulting two-dimensional distributions showed a plume of methane-rich and sulfate-depleted pore water reaching from a depth below $1.2 \mathrm{~m}$ beneath the sand surface up to the sediment surface at the low-water line. The $\delta^{13} \mathrm{C}$ of methane released at the seeps was $-68.6 \%$, indicating a biological origin. The ${ }^{14} \mathrm{C}$ signature of methane was clearly elevated by anthropogenic radiocarbon, which shows that the methane was formed less than $50 \mathrm{yr}$ ago. The observations indicate an internal circulation, where water enters the sand flats in the central area and exits at the low-water line. Pore-water flow patterns in the sand flat during the tidal cycle were calculated from the surface topography and from the pressure distribution at the flat surface across the tidal cycle. The calculated flow patterns explain the measured methane and sulfate distributions and predict a residence time of the seepage water of about $30 \mathrm{yr}$. Intertidal sand flats act as one-way valves, passing water from the central surface through the interior of the flat to an outflow zone at and below the low-water line with a velocity of millimeters to centimeters per day. The flow causes permeable tidal flats to emit methane to the surface water and atmosphere in substantial amounts.
\end{abstract}

The Wadden Sea is one of the largest coherent tidal flat systems in the world. It is separated from the North Sea by a chain of barrier islands across $500 \mathrm{~km}$ of coastline from Den Helder in the Netherlands, across the German coast to Blåvands Huk in Denmark (Fig. 1). The tidal range is between $3.5 \mathrm{~m}$ in the central part and $1.2 \mathrm{~m}$ in the northernmost and southernmost areas (van Beusekom 2005). The original ecosystems of the Wadden Sea were salt marshes, mudflats, and sea grass beds that developed after the last ice age. The salt marshes disappeared because of peat harvesting, and the floodplain areas decreased, primarily because of land reclamation. Thus, the sediments of the Wadden Sea are changing via a gradual displacement

\footnotetext{
${ }^{1}$ Present address: Center for Geomicrobiology, Department of Biological Sciences, University of Aarhus, Ny Munkegade 1535, DK-8000 Århus C, Denmark.

2 Present address: National Fisheries Research and Development Agency, Kijang-Kun, Pusan 626-900, Korea.

${ }^{3}$ Present address: TNO Built Environment and Geosciences, Princetonlaan 6, 3584 CB Utrecht, the Netherlands.

\section{Acknowledgments}

We thank the skippers Ronald Monas of the tjalk Spes Mea and Iso Speck of the Larus for sharing their knowledge of the Wadden Sea, for their help during cruises, and for letting us use their ships in unusual ways. We gratefully acknowledge Helmut Erlenkeuser (Leibniz Laboratory for Radiometric Dating and Stable Isotope Research, Kiel, Germany) for the isotope analyses and help with the interpretations, and Alicia M. Wilson for her valuable comments and advice on the modeling of flow. Ingrid Dohrmann and Antje Voßmeyer are thanked for technical assistance, and Bert Engelen, Hans-Jürgen Brumsack, Heribert Cypionka, and Jürgen Rullkötter (ICBM, Oldenburg, Germany) for cooperation and scientific discussions. Markus Billerbeck provided access to his extensive data on the field site. The study was supported by the Deutsche Forschungs Gemeinschaft grant FOR432 (Forschergruppe WATT) and by the Max Planck Society.
}

of silt with sands, especially toward the barrier islands and the large tidal channels where intertidal sand flats now dominate (Lotze 2005).

The incentive for this study was methane ebullition and seepage of sulfidic pore water observed at the low-water line of the intertidal sand flat Janssand. A former study (Billerbeck et al. 2006a) concentrated on nutrient fluxes carried by relatively surficial flow. This study aims to identify the source and pathway of the methane-rich water that seeps out near the low-water line, i.e., the deeper part of what was defined as body flow (Billerbeck et al. 2006b). Methane is globally one of the largest reservoirs of organic carbon. It is a powerful greenhouse gas, and therefore the global budgeting of sources and sinks is of great importance. Searches for marine sources of methane are focused on deep-sea seepage through mud volcanoes and gas hydrate bearing sediments. This methane source is fossil organic matter. In these areas most methane transported toward the oxic biosphere is removed by anaerobic methane oxidation coupled with sulfate reduction (Boetius et al. 2000; Elvert et al. 2005; Treude et al. 2005; de Beer et al. 2006). The release rate of methane from the seabed and benthic oxidation rates are still poorly constrained because of lack of understanding of the controlling factors. The kinetics of anaerobic methane oxidation is slow compared with other microbiologically catalyzed sediment processes, and this allows the broad coexistence of sulfate and methane at turnover times of months to years (Jørgensen et al. 2001). Special conditions, for example by pore-water flow or gas ebullition by excessive methane accumulation, enable the methane to escape up through the sulfate barrier (Martens and Klump 1980). Methanogenesis is thought to be of little importance in shallow coastal areas, since the degradation of organic matter is dominated by aerobic respiration and sulfate reduction (Reeburgh 1983). However, tidal estuaries are 


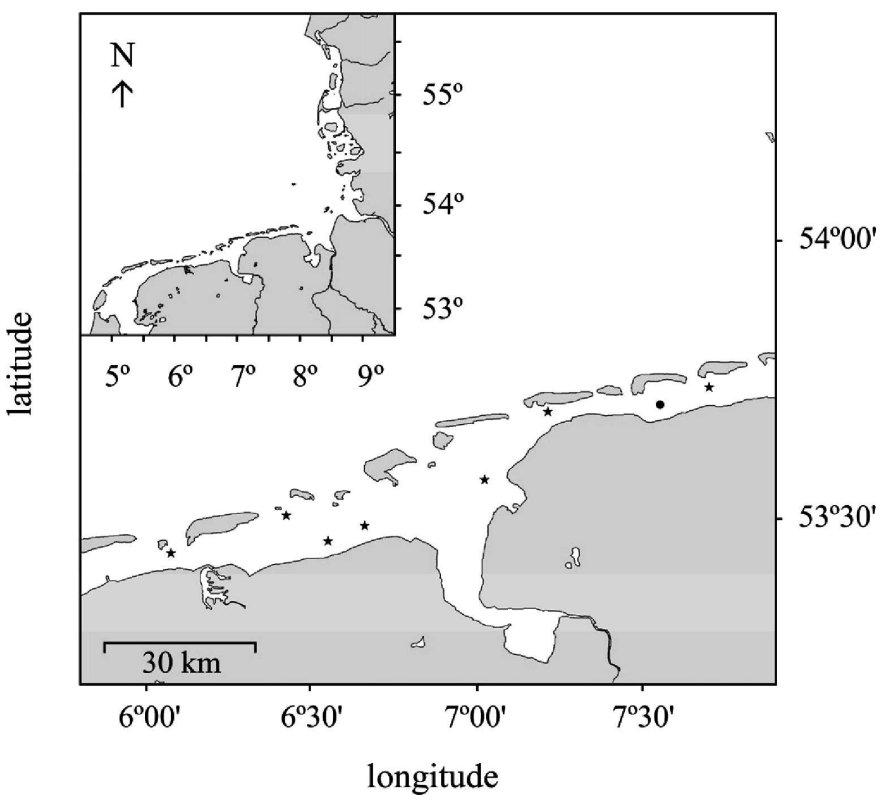

Fig. 1. Map of sampling locations. Sites with methane ebullition are marked with stars. From west to east the sites are Engelsmanplaat, Simonszand, Zuid-Oost Lauwers, Horsbornzand, Kopersand, Hohes Riff, and Janssand. Ruteplate, where no methane ebullition was observed, is marked with a circle. The insert shows the entire Wadden Sea from Den Helder in the Netherlands, across the German coast to Blåvands Huk in Denmark.

known to liberate methane (Middelburg et al. 2002). The observed methane ebullition at Janssand indicates the presence of special factors in intertidal sand flats that lead to methane formation and to its escape from the seafloor.

Our main questions were: What is the mechanism behind methane release from intertidal sand flats? and Is it a common phenomenon? We therefore investigated the pathway that carries the methane-rich water to the edge of the tidal flat. Also we determined the origin and the age of the escaping methane. We investigated one main study site in detail, where the two-dimensional structure of the seep was determined, and the pore-water flow distribution was modeled. A less detailed survey was performed during a 2-week cruise across the western Wadden Sea from Ameland in the Netherlands to Spiekeroog in Germany (Fig. 1) to assess whether methane- and sulfide-rich seeps are common.

\section{Methods and study sites}

Primary field site - The main study site on Janssand near Neuharlingersiel in the German Wadden Sea was visited repeatedly from 2004 to 2006 . The study site $\left(53^{\circ} 44.11^{\prime} \mathrm{N}\right.$, $7^{\circ} 41.95^{\prime} \mathrm{E}$ ) is situated on the western edge of the flat facing the $17-\mathrm{m}$ deep tidal channel that separates the barrier islands Spiekeroog and Langeroog. The flat consists of well-sorted silica sand with discontinuous mud lenses below the surface. The tidal range is about $2.7 \mathrm{~m}$ (measured at a tidal gauge $2 \mathrm{~km}$ away), and $1.9 \mathrm{~m}$ of sediment column is exposed during low tide. The entire flat is inundated for $6-$ $7 \mathrm{~h}$ during each semidiurnal tidal cycle. The permeability ranges between $7.2 \times 10^{-12} \mathrm{~m}^{2}$ at the upper flat and $5.2 \times$ $10^{-13} \mathrm{~m}^{2}$ at the low-water line (Billerbeck et al. 2006a). Seeps can be observed along the entire exposed eastern edge of the flat.

Secondary field sites - Seven additional intertidal flats between Janssand and the island Ameland in the Netherlands were visited in October 2006 with the tjalk Spes Mea, a flat-bottom ship that can fall dry during low tide. The ship was grounded at the edges of the flats during falling tide, and areas of ca. 2-km distance from the ship could be safely explored during low tide. Seeps were identified by strong sulfide smell, blackened sediment, milky suspensions of elemental sulfur, and bubbles released from the sediment. The topographies of the visited sites were measured and pore water was analyzed for methane, chloride, and sulfate (see below).

The locations visited are marked on Fig. 1 and were the Engelsmanplaat $\left(53^{\circ} 26.2^{\prime} \mathrm{N}, 06^{\circ} 04.4^{\prime} \mathrm{E}\right)$, the Simonszand $\left(53^{\circ} 30.3^{\prime} \mathrm{N}, 06^{\circ} 25.3^{\prime} \mathrm{E}\right)$, the Zuid-Oost Lauwers $\left(53^{\circ} 27.5^{\prime} \mathrm{N}\right.$, $\left.06^{\circ} 32.8^{\prime} \mathrm{E}\right)$, the Horsbornzand $\left(53^{\circ} 29.17^{\prime} \mathrm{N}, 6^{\circ} 39.46^{\prime} \mathrm{E}\right)$, the Kopersand $\left(53^{\circ} 34^{\prime} \mathrm{N}, 07^{\circ} 01^{\prime} \mathrm{E}\right)$, the Hohes Riff $\left(53^{\circ} 41.5^{\prime} \mathrm{N}\right.$, $\left.07^{\circ} 12.7^{\prime} \mathrm{E}\right)$, the Ruteplate $\left(53^{\circ} 42.24^{\prime} \mathrm{N}, 7^{\circ} 32.45^{\prime} \mathrm{E}\right.$ to $\left.53^{\circ} 42.26^{\prime} \mathrm{N}, 7^{\circ} 33.10^{\prime} \mathrm{E}\right)$, and Janssand $\left(53^{\circ} 44.11^{\prime} \mathrm{N}, 7^{\circ} 41.95^{\prime} \mathrm{E}\right)$.

Surface topography measurement-The surface topography was measured using a 50-m long transparent polyvinyl chloride (PVC) hose $(5 \mathrm{~mm}$ inner diameter) filled with water. One end of the PVC tube was aligned with a 2-m long pole marked with ruler tape and placed at a fixed point of reference. One person then moved in steps of 2 $10 \mathrm{~m}$ along transects of interest and carefully aligned the meniscus at a fixed height above the sediment at each point. A second person measured the height of the meniscus at the reference pole. Finally, all values were referenced to the low-water line. This method has an accuracy of ca. $0.5 \mathrm{~cm}$.

Pore-water analysis - Oxygen and $\mathrm{H}_{2} \mathrm{~S}$ microprofiles were measured during full tidal cycles to maximally 10 $\mathrm{cm}$ depth with Clark-type microsensors using an autonomous profiling unit as described previously (de Beer et al. 2004).

Subsurface samples for methane and sulfate were acquired by driving a stainless steel pipe (inner diameter $35 \mathrm{~mm}$ ) to defined depths in the sediment with a hammer. The upper end of the pipe was corked and the pipe partly dug free to avoid losing sediment core or pore water during retrieval. Duplicate 2-mL samples were then taken with cut syringes from the lower opening of the pipe and transferred to $12-\mathrm{mL}$ Exetainers preloaded with $1 \mathrm{~mL} 2.5 \% \mathrm{NaOH}$ or $1 \mathrm{~mL} \mathrm{20 \%} \mathrm{Zn} \mathrm{acetate.} \mathrm{Samples} \mathrm{preserved} \mathrm{with} \mathrm{Zn}$ acetate were later analyzed for $\mathrm{Cl}^{-}$and $\mathrm{SO}_{4}^{2-}$ in the supernatant by ion chromatography. Samples preserved with $\mathrm{NaOH}$ were analyzed for methane in the headspace by gas chromatography on a 1.83 m Poropack Q column with a flame-ionization detector.

Methane and sulfate distributions in the pore water were measured along transects from the low-water line up to 
$120 \mathrm{~m}$ from the low-water line toward the central flat. Typical vertical and horizontal resolutions were 0.4 and $6 \mathrm{~m}$, respectively. The data were interpolated on a 1- by 5 $\mathrm{cm}$ grid by triangulation with linear interpolation. Finally the gridded data were smoothed with a $10-\mathrm{cm}$ matrix $(11 \times$ 3 grid points) and areas outside the boundary of the measurements blanked. The use of a smoothing matrix much smaller than the resolution of the raw data ensures minimal manipulation of the measured points, but produces continuous isolines.

Analysis of escaping gas-To avoid contamination with ${ }^{14} \mathrm{C}$, all sample materials were new and carefully rinsed with ambient seawater. Methane for isotope analysis was collected in 1.5-liter polypropylene bottles from ebullition below the low-water line. The bottles were prefilled with ambient seawater and inverted under water, and a funnel was inserted in the opening by which emerging bubbles were caught. The gas was transferred to new crimp-sealed glass bottles supplied by the Leibniz Laboratory for Radiometric Dating and Stable Isotope Research, and mailed from the field site directly to the same laboratory for analysis. Here the composition of the raw samples was measured by accelerator mass spectroscopy (AMS). $\mathrm{CO}_{2}$ and $\mathrm{CH}_{4}$ were separated by sweeping through a cold trap at $-196^{\circ} \mathrm{C}$ with the escaping $\mathrm{CH}_{4}$ fed into a combustion line at $870^{\circ} \mathrm{C}$ together with excess $\mathrm{O}_{2}$, and the resulting $\mathrm{CO}_{2}$ was trapped cryogenically. In a second step the original $\mathrm{CO}_{2}$ fraction left in the first cold trap was swept through the oven and collected. Aliquots of both $\mathrm{CO}_{2}$ fractions were reduced with $\mathrm{H}_{2}$ over Fe powder. The resulting carbo$\mathrm{n}$ : iron mixtures were pressed into pellets and measured on a Tandetron 4130 AMS. The ${ }^{14} \mathrm{C}$ concentration was measured by comparing the simultaneously collected ${ }^{14} \mathrm{C}$, ${ }^{13} \mathrm{C}$, and ${ }^{12} \mathrm{C}$ beams of the sample together with oxalic acid standard $\mathrm{CO}_{2}$ and coal background material. The ${ }^{14} \mathrm{C}$ concentration was corrected according to Stuiver and Polach (1977) based on the ${ }^{13} \mathrm{C}:{ }^{12} \mathrm{C}$ ratio from the same AMS run.

Calculations of pore-water flow-The pore-water flow in Janssand was calculated in the Earth-Science module of Comsol Multiphysics (www.comsol.com). The software can calculate, for example, pore-water flow in an arbitrary geometry by dividing into finite elements. The software is often used for geophysical or hydrological modeling (e.g., Cardenas and Wilson 2006). The body flow was simulated according to Darcy's law:

$$
\text { water flux }=-k / \mu \times \nabla P
$$

where $k$ is the permeability, $\mu$ is the dynamic viscosity, and $\nabla P$ is the pressure gradient vector. To achieve the velocity in the pore space, the flux must be divided by porosity to account for the fact that the flow is constrained to this fraction of the bed volume.

The geometry of the model was based directly on a measured surface profile from $20 \mathrm{~m}$ seaward from the lowwater line and $120 \mathrm{~m}$ onto the exposed sand flat. The measured geometry was extrapolated another $80 \mathrm{~m}$ sea- ward based on sea charts, and $480 \mathrm{~m}$ to the center of the sand flat assuming no further change in topography. The shape of the sand flat is well approximated by a circular disc and therefore modeled as radial symmetric. The calculation grid consisted of 50,771 triangular elements with a $20 \times 10 \mathrm{~cm}$ (horizontal $\times$ vertical) resolution at the sediment-water interface.

Permeability and porosity was available for the surface layers of the 6-m thick sandy deposit that forms Janssand and from the muddy inclusions found at the low-water line (Billerbeck et al. 2006b). To constrain the influence of unknown permeability inside the bed three calculations were performed under different assumed permeability regimes: (1) Isotropic permeability of $7.2 \times 10^{-12} \mathrm{~m}^{2}$. (2) Isotropic permeability of $5.2 \times 10^{-13} \mathrm{~m}^{2}$. (3) Anisotropic permeability with $7.2 \times 10^{-12} \mathrm{~m}^{2}$ horizontal permeability and $5.2 \times 10^{-13} \mathrm{~m}^{2}$ vertically. The clay layer, found below 6-m depth (Bert Engelen pers. comm.), was assigned a permeability of $10^{-15} \mathrm{~m}^{2}$ in all cases. The viscosity of the pore water was assumed to be constant $\left(1.3 \times 10^{-3} \mathrm{~Pa} \mathrm{~s}\right)$.

As boundary conditions we imposed no flow across the bottom of the modeled domain, the vertical center boundary, and the vertical seaward boundary. Note that these boundaries are far remote from the seep sites. The pressure at the sediment surface, i.e., the upper boundary condition, is the driving force behind the pore-water flow. The exposed surface was assigned with atmospheric pressure, and inundated parts were assigned with atmospheric plus hydrostatic pressure. The dynamic tidal height was acquired from a gauge $2,000 \mathrm{~m}$ from the station.

Near the edge we observed that the water table in shallow wells was up to $20 \mathrm{~cm}$ below the exposed surface, though the sediment remained water saturated. Thus, this area is covered by a zone with a pore-water pressure lower than air pressure, caused by capillary force. This volume, which was carefully mapped, is not modeled since it falls outside the defined boundary.

A complete tidal cycle from one high water to the next was calculated with 2-min temporal resolution of the output. At the starting point the entire sand flat was inundated and the hydrostatic pressure therefore uniform. This was reflected by setting the initial condition to zero velocity. After the full cycle was calculated the flow was averaged across the tidal cycle to allow calculation of pore paths and water residence time.

To verify the numerical method, selected scenarios were calculated with the calculation domain extended in depth and radius and with denser grid. The numerical solution was independent of boundaries and grid density. Internal temporal resolution was managed automatically by Comsol Multiphysics, and no numerical oscillations occurred.

\section{Results}

General description of Janssand seep areas-The Janssand has a surface area at low tide of ca. $3 \mathrm{~km}^{2}$. The central area is almost flat and is ca. $1.9 \mathrm{~m}$ elevated above the lowwater level. At its periphery the intertidal sand flat slopes down to the low-water line over a distance of ca. $50 \mathrm{~m}$. The 


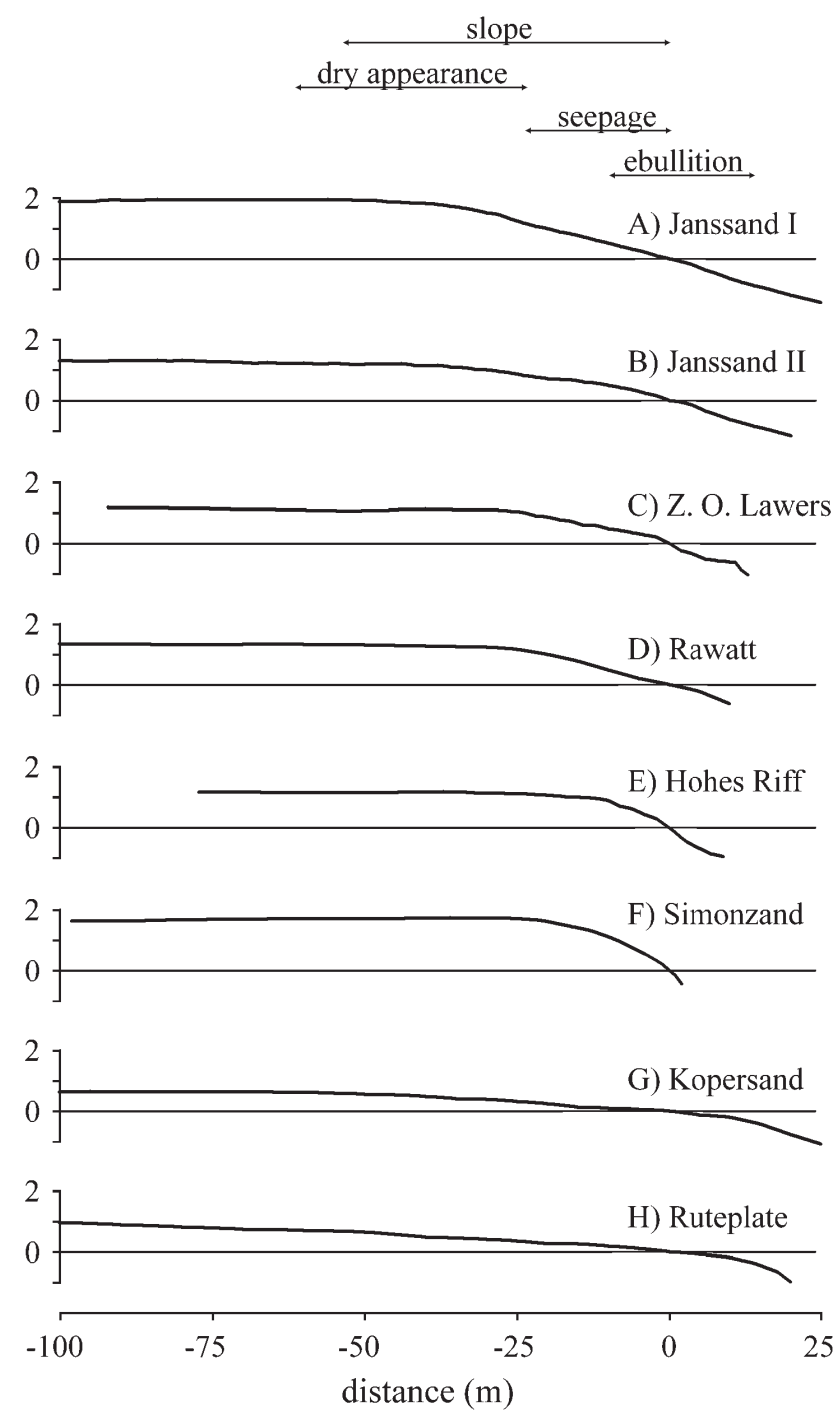

Fig. 2. (A-H) Topographic profiles of the tidal flats measured perpendicular to the waterline.

transition from the sand flat is rather sharp, and the slope is distinct (Fig. 2).

Seeps are found both on the eastern edge of Janssand and along tidal channels that cut into the sand flat. The seep areas are, on superficial inspection, not different from inactive sites. They consist of sandy sediment with the same grain size as that of surrounding nonseeping sediments $(\sim 176 \mu \mathrm{m}$ mean). However, the sediment is often unconsolidated at the seep area, and the observer can sink in unexpectedly. The seep areas are remarkably devoid of benthic macrofauna. The lower half of the slope has a wet seepage face during low tide. Correspondingly, the area near transition from the flat interior to the slope is devoid of surface water and appears dry relative to the interior of the flat and to the seepage face (Fig. 2). However, air does not enter the pore space. Black spots appear within ca. $30 \mathrm{~min}$ after exposure where sulfidic pore water seeps out. In stagnant pools the seawater turns milky by precipitation of elemental sulfur, probably because of iron-catalyzed sulfide oxidation. The area can be recognized from distance by a strong sulfidic smell. Bubbles are often visible and audible near the low-water line but more obvious on the subtidal sediments. Typical seeps cover 10 to $100 \mathrm{~m}$ along the low-water line.

From June to October the seep areas are characterized by patches of bright green flagellates that migrate up to the surface ca. $1 \mathrm{~h}$ after regression of the tide. Diatoms are also abundant, but separate from the flagellates, forming a colorful mosaic that follow the microtopography of ripples and gullies.

Pore-water chemistry-Close to the low-water line sulfide reaches the surface during low tide (Fig. 3A). Shortly after inundation the sulfide is depleted in the upper $5 \mathrm{~mm}$ and the profile remains stable for the rest of the inundation period. Oxygen did not penetrate the sediments during low tide, but it penetrated 5-mm deep during high tide (Fig. 3B). In the central area, no sulfide could be detected in the upper $10 \mathrm{~cm}$. Oxygen penetration was 2$5 \mathrm{~mm}$ during low tide and $10-15 \mathrm{~mm}$ during high tide (data not shown).

Methane and sulfate distributions in the pore water were measured along transects from the low-water line up to $120 \mathrm{~m}$ from the low-water line toward the central area in March, June, and October 2005 and April 2006. The concentration measurements were complicated by an uncertain porosity of the retrieved sample and by compaction during the coring. Coring each depth separately assured that the sediment sampled in the end of the core could be ascribed to the correct depth regardless of compaction of the core during penetration. Although the individual concentration measurements were not very accurate, in combination they yielded consistent spatial patterns. Two-dimensional reconstruction showed a plume of methane-saturated pore water with less than $1 \mathrm{mmol}$ $\mathrm{L}^{-1}$ sulfate, reaching upward from below $120 \mathrm{~cm}$ near the low-water line (Figs. 4, 5). One transect was made parallel to the waterline, $42 \mathrm{~m}$ from the low-water line, crossing a temporary tidal channel. Clearly, a plume of sulfatedepleted and methane-rich pore water was reaching upward to the bed of the small channel (Fig. 6). This indicates pressure driven flow, following the path of lowest resistance. The depression eroded by the tidal channel forms a path with less resistance, which becomes a preferred flow path upward. The main seep area was observed at $53^{\circ} 44.11^{\prime} \mathrm{N}, 7^{\circ} 41.95^{\prime} \mathrm{E}$. In 2004 a large seep developed ca. $500 \mathrm{~m}$ farther north in a newly developed tidal channel. The seeps generally have slow dynamics independent from season and focus in lower points of the topography. The $\mathrm{Cl}^{-}$concentrations could not be distinguished from seawater anywhere in the sediment.

Isotopic composition of the escaping gas-The gas collected at the subtidal zone consisted of $\mathrm{CH}_{4}$ and $\mathrm{CO}_{2}$ in a roughly 5:1 ratio, a minor fraction of $\mathrm{O}_{2}$ and $\mathrm{N}_{2}$ in atmospheric ratio, and traces of $\mathrm{H}_{2} \mathrm{~S}$. The $\delta^{13} \mathrm{C}$ value of the methane was $-69 \pm 0.14 \%$, typical for methane of biological origin. The value for the $\mathrm{CO}_{2}$ was $-16 \pm$ $0.86 \%$, similar to $\mathrm{CO}_{2}$ from biomass oxidation and clearly below dissolved organic carbon of seawater (around 0) 

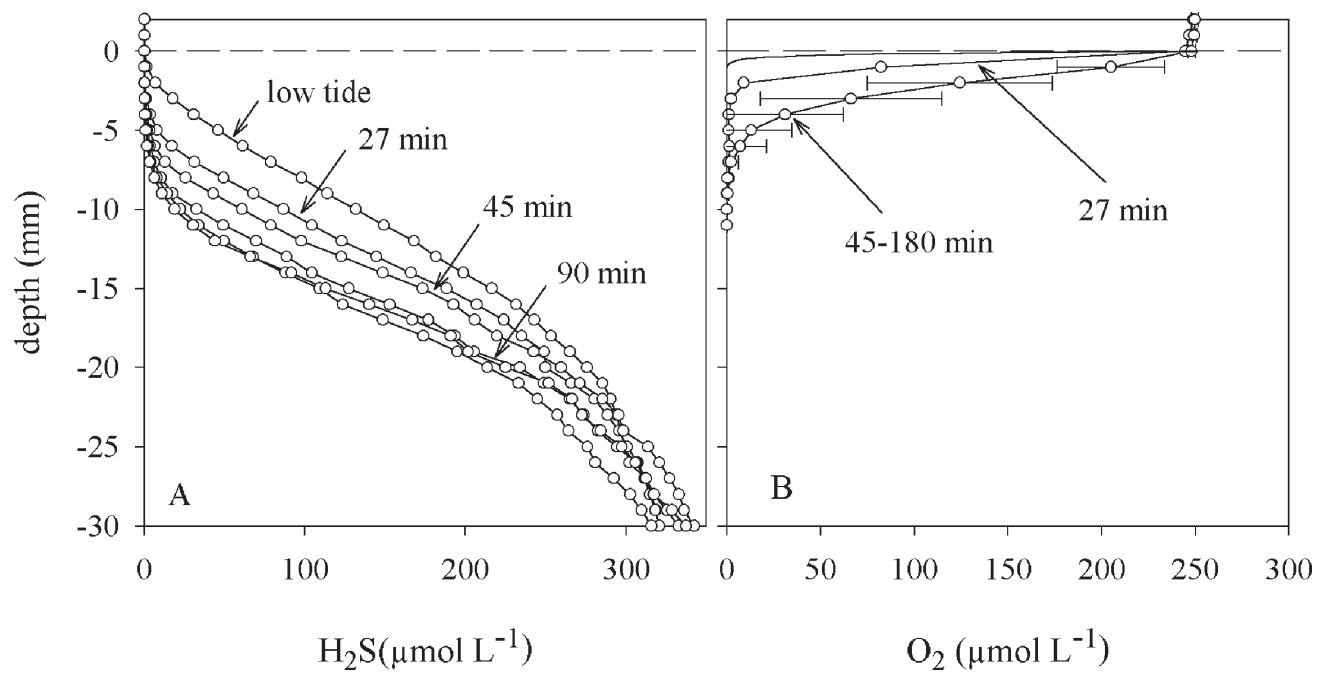

Fig. 3. (A) $\mathrm{H}_{2} \mathrm{~S}$ distribution in seeping sediment measured repeatedly across the transition from ebb to flood. Zero depth represents the sediment-water interface. Numbers at individual profiles indicate the time that the sediment had been inundated when the profile was started. (B) $\mathrm{O}_{2}$ distribution in seeping sediment measured every repeatedly across the transition from ebb to flood. During low tide the $\mathrm{O}_{2}$ penetrated less than the 1-mm step size used and the line representing this is therefore conceptual. The profile with the deepest penetration represents the average of five consecutive profiles $( \pm \mathrm{SD})$ with no trend in time.

(Peterson and Fry 1987). The ${ }^{14} \mathrm{C}$ content of the $\mathrm{CH}_{4}$ was $125.97 \pm 0.35$ percent modern $(1950)$ carbon $(\mathrm{pMC})$, and the $\mathrm{CO}_{2}$ was $123.16 \pm 0.43 \mathrm{pMC}$, both corresponding to the atmospheric level of around 1984. Classic radiocarbon age determination is not possible from material with ${ }^{14} \mathrm{C}$ content above $100 \mathrm{pMC}$, but the age can still be constrained in a narrow window. The source of the excess ${ }^{14} \mathrm{C}$ is the hydrogen bomb tests in the early 1960 s, which
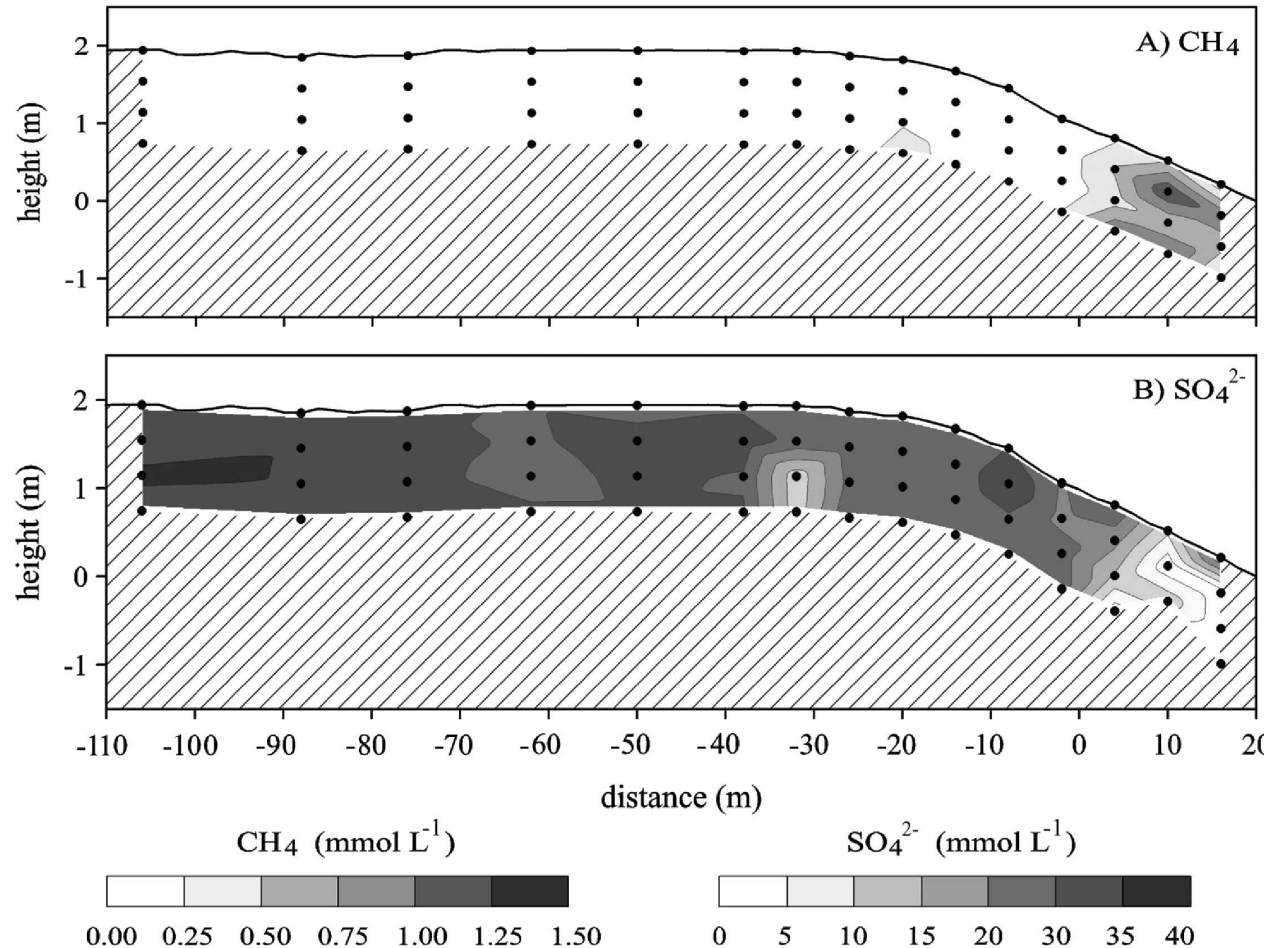

B) $\mathrm{SO}_{4}^{2-}$

Fig. 4. Distribution of (A) methane and (B) sulfate in a cross section of the edge of Janssand measured in July 2005. The circles indicate points sampled for methane and sulfate. The hatched area was outside the boundary of the measurements. The origin of the coordinate system is the waterline at low tide. 

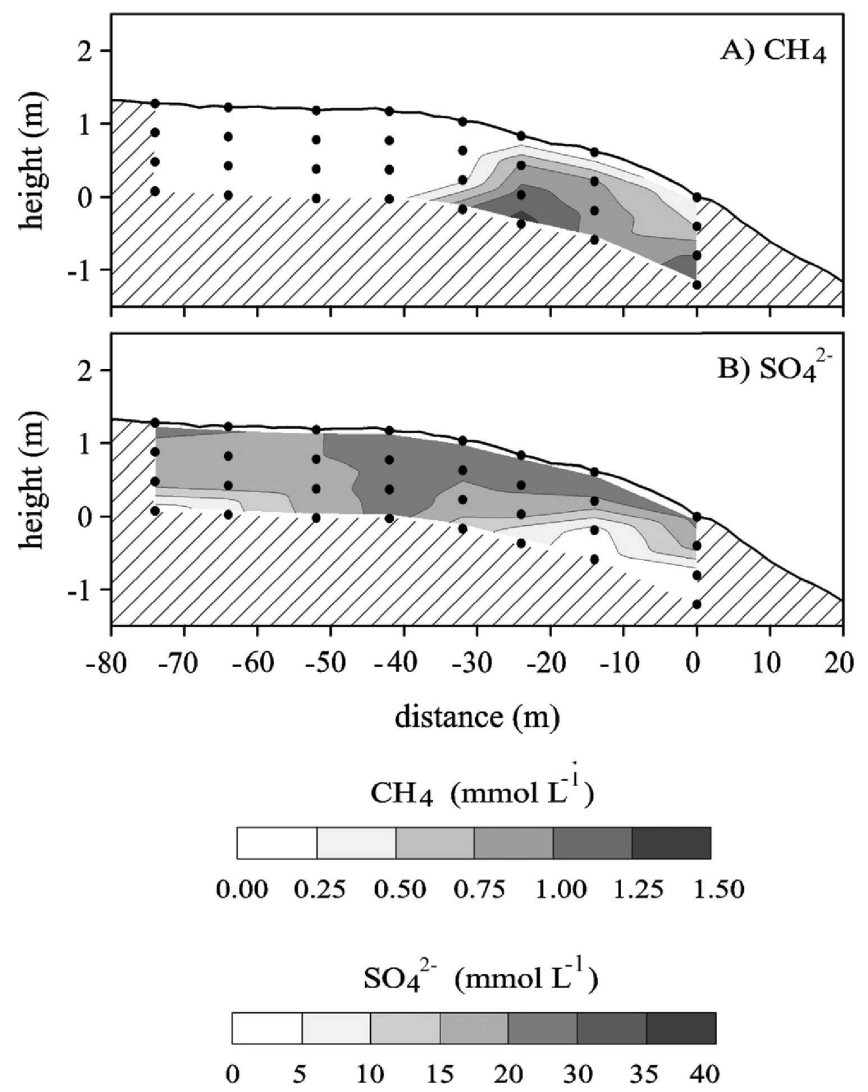

Fig. 5. Distribution of (A) methane and (B) sulfate in a cross section of the edge of Janssand measured in March 2005. The hatched area was outside the boundary of the measurements. The origin of the coordinate system is the waterline at low tide.

contributed a strong pulse of ${ }^{14} \mathrm{C}$ to the atmosphere. The ${ }^{14} \mathrm{C}$ levels were clearly above those from before 1950; thus the methane and dissolved inorganic carbon (DIC) originates from degrading biomass, fixed by photosynthesis less than $50 \mathrm{yr}$ ago.

Finite element modeling-The finite element modeling predicts flow of water into the sand flat toward the central parts and flow out of the flat around the low-water line. The border between inflow and outflow is on the middle of the slope (Fig. 7). This corresponds with the observed border between the area devoid of surface water and the permanent wet part of the slope. The area near the inflowoutflow transition, between 20 and $30 \mathrm{~m}$ from the lowwater line, is characterized by a fast-moving shallow flow. The shallow flow paths in this area are highly influenced by ephemeral topography and thus will vary strongly in time. The most accurate statement is that the surface sediment in this area is intensively flushed and the calculated flow path is not shown in Fig. 7. These fast-moving waterbodies close to the edge are neither sulfate depleted nor enriched in methane (Figs. 4, 5). Water that seeps out of the lower $\sim 15 \mathrm{~m}$ of the slope followed a longer and deeper path that originates within $75 \mathrm{~m}$ from the low-water line. The predicted residence time was between 3 and $30 \mathrm{yr}$, based
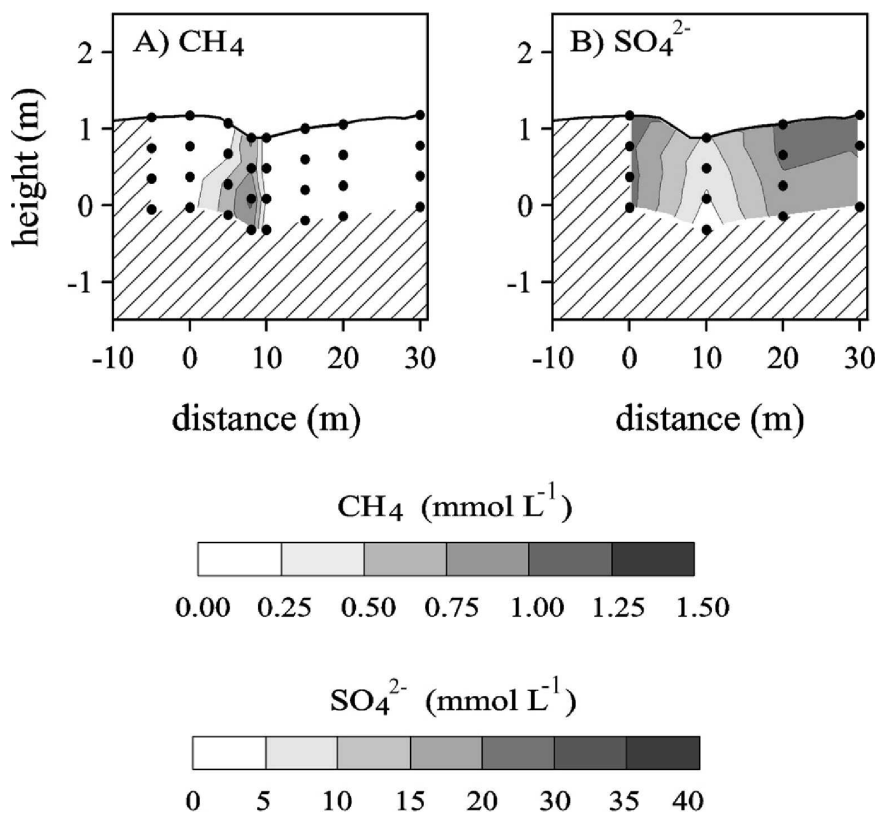

Fig. 6. Distribution of (A) methane and (B) sulfate across a temporal tidal creek. The transect is perpendicular to the profile in Fig. 4, crossing this $42 \mathrm{~m}$ from the low-water line. The distance on the $x$ axis is relative to the profile in Fig. 4. The hatched area was outside the boundary of the measurements. The origin of the coordinate system is the waterline at low tide

on the lowest assumed permeability (Fig. 7). The slowmoving deeper waterbodies coincide with the observed sulfate-depleted and methane-rich plume. Outflow of pore water continues below the low-water line, but the velocity

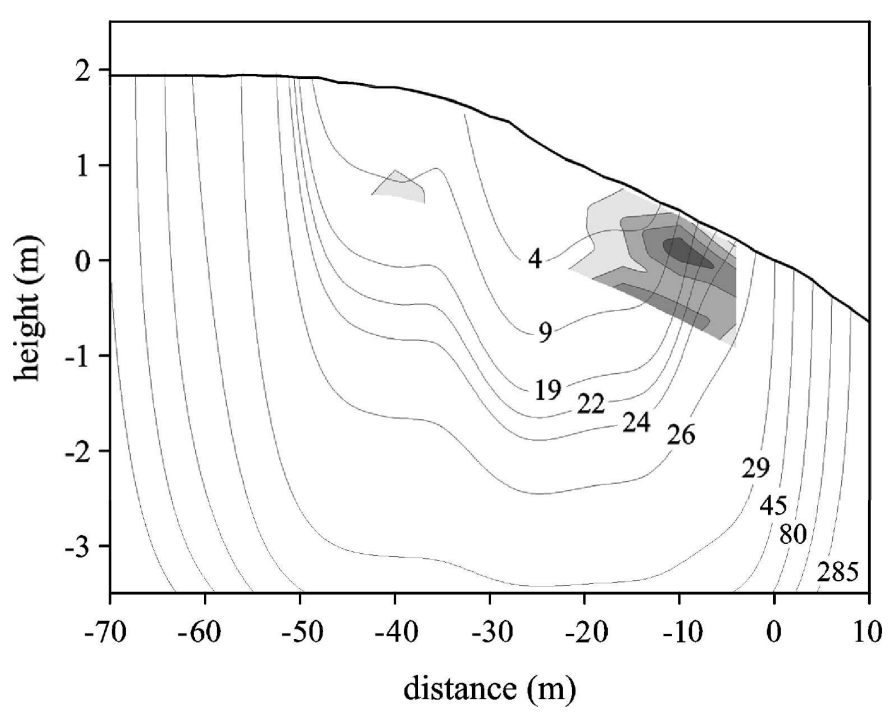

Fig. 7. Calculated pathway of the body flow. The numbers on the flow lines indicate the number of years it takes for a water parcel to travel along the line from the surface, through the sediment, to the seep. Note that the different scales on the $x$ and $y$ axis make the flow paths look much more curved than they are. The grayscale overlay is identical to the methane data presented in Fig. 4. 
decays about $50 \%$ for every $2 \mathrm{~m}$. Consequently, the pore water seeping out of the tidal flat in the subtidal zone had a very long residence time (see Web Appendix, www.aslo.org/ lo/toc/vol_53/issue_4/1521al.mpg, for an animation of the flow through the tidal cycle).

The calculated water flux and pore-water age of the methane-rich water depends linearly on the assumed permeability of the sand flat. Using the minimum permeability as above, the water flux out of the lower $10 \mathrm{~m}$ of the slope is $0.5 \mathrm{~L} \mathrm{~m}^{-2} \mathrm{~d}^{-1}$. This flux is integrated over the tidal cycle and includes the time of stagnation while the entire flat is submerged. The permeability of the central area of the Janssand is 14 times higher than near the low-water line (Billerbeck et al. 2006b). Consequently, the water flux could be up to 14 times higher, i.e., $7 \mathrm{~L} \mathrm{~m}^{-2} \mathrm{~d}^{-1}$. The water fluxes correspond to a pore-water displacement in the order of $1 \mathrm{~mm}$ to $1 \mathrm{~cm} \mathrm{~d}^{-1}$ in the methane-saturated plume.

Seepage at flats in other locations of the western Wadden Sea-To assess whether the observations made on Janssand are of a general nature we visited seven additional locations between Ameland (the Netherlands) and Spiekeroog (Germany) during October 2006. The assessment of seep activity was made by observing ebullition and black spots and sampling of sediments for sulfide, methane, sulfate, and grain size determination. Furthermore, topography measurements were made of the inspected sites.

Seeping of methane-saturated pore water $(\sim 1.3 \mathrm{mmol}$ $\mathrm{L}^{-1}$ ) was observed at all sand flats visited (Engelsmanplaat, Simonszand, Zuid-Oost Lauwers, Horsbornzand, and Hohes Riff). All seeping flats had similar topography as Janssand, and the same patterns of wet seepage zones on the slopes were apparent (see Fig. 2A-E for profiles of seeping flats). Hohes Riff, though, only had seepage below the low-water line. All surfaces of seeps were devoid of macrofauna, whereas nonseeping areas of the same flats were inhabited by polychaetes and bivalves. Euglenoid flagellates were often observed as green stains near, but not on, seepage areas. Sand flats had seepage along $10-50 \%$ of the low-water line, with each seepage site being 10 to several hundreds meters wide. The consistent features of seeping intertidal plates was a wellsorted sand body and a distinct profile with a large flat interior area and a distinct slope down to a tidal channel. Seeps can easily be found near the low-water line of permeable sand flats, smell sulfidic, show black spots in between the ripples, are devoid of macrofauna, and are often quicksand.

The sites without seepage were always associated with fine-grained sediments. Simonzand, for example, did not have seepage along the western edge where an apparently continuous $10-\mathrm{cm}$ thick clay layer was found $\sim 50 \mathrm{~cm}$ below the surface of the sediment (Fig. 6F). The eastern edge of Simonzand was not capped by clay and had seepage. Kopersand and Ruteplate both consisted of mud-mixed sand and had no seepage (Fig $2 \mathrm{G}-\mathrm{H}$ ). Horsbornzand and Zuid-Oost Lauwers had both muddy and sandy areas, and seepage was confined to the sand.

\section{Discussion}

Advection has long been recognized as the main transport mechanism for solutes near the surface of permeable sands, as well as for exchange between sediment and water column (Riedl et al. 1972; Rutgers van der Loeff 1980). Transport in the upper few centimeters of submerged sediments (skin flow) is controlled by the boundary-layer flow over surface topography (Thibodeaux and Boyle 1987; Precht and Huettel 2003) and drives concentration dynamics on the time scale of seconds to minutes (de Beer et al. 2004; Werner 2005). Owing to skin flow, degradation products do not accumulate and electron acceptors do not deplete in the upper few centimeters of sandy beds (e.g., Rutgers van der Loeff 1980), although aerobic and anaerobic mineralization processes occur with high areal rates. Skin flow is characteristic of all permeable sediments in shallow waters.

It was recognized recently that the biogeochemistry of the Janssand is under control of a second transport phenomenon (Billerbeck et al. 2006a), referred to as body flow. The sand flats stay water saturated during low tide because the drainage through the sediment is slow and because the pore water is replenished by water caught in small depressions in the otherwise level surface. The body flow is driven by the pressure head caused by elevation of the pore water relative to the sea surface at low tide. On the Janssand, the low-water line is $1.9 \mathrm{~m}$ below the top of the sand flat; thus a pressure head of $1.9 \mathrm{~m}$ drives pore-water flow through the sediment from the center of the flat to the low-water line where it seeps out. Flooding eliminates the pressure head and stops the flow during high tide, but the pressure gradient is not reversed. Thus, the pore-water flow is one way from the top of the intertidal flat to the waterline with one displacement pulse each low tide (see also Jahnke et al. 2003; Billerbeck et al. 2006b; Gardner and Wilson 2006). The process is similar to the percolation of beaches caused by wave swash (Riedl et al. 1972) and tidal pumping (Webster et al. 1994). But in the case of intertidal flats in the Wadden Sea the infiltration zone comprises the entire sand flat. As these flats are hydraulically separated from the islands and mainland by tidal channels, the lack of a freshwater aquifer makes the system fully marine (compare with Nielsen 1990).

The pore water in seeps along the low-water line of Janssand contains high concentrations of nutrients, which vary in time independent of seasons (Billerbeck et al. $2006 a$ ). High seepage activity was observed in December 2001, December 2002, June 2003, and March 2004, while the seeping activity was low between March and September 2002. Methane seeping activity can appear in one area, remain active over several months, and decrease and appear in other locations with no apparent seasonal pattern. This can be explained by the slow dynamics of the flow and by the influence of the sand flat topography, which is irregularly eroded and redeposited. Erosion will form an area with less resistance and thereby focus the seepage. This is illustrated by the observed upward plume of methane-rich and sulfate-depleted pore water under the shallow channel cut into the main flat of the Janssand 
(Fig. 6). If the flat is extended by $1 \mathrm{~m}$ due to redeposition of sand during a storm, it will take between 100 and 1,000 d before the methane-rich sulfidic pore-water flow will reach the surface again, since it flows $1-10 \mathrm{~mm} \mathrm{~d}^{-1}$. Erosion and redeposition leading to horizontal changes in the waterline of several meters per year are observed at Janssand, and this must cause temporal variability with the time scales observed.

Leakage of sulfidic pore water and ebullition of methane was found at all sand flats inspected during this study. The presence of methane in tidal estuaries of large rivers has been reported at various locations in Germany, the Netherlands, Belgium, England, France, Spain, and Portugal. A part of the methane was identified to originate with large likelihood from tidal flats and creeks; however, the nature of the source was not resolved (Middelburg et al. 2002). Very likely the methane sources were permeable intertidal flats that delivered methane into the tidal creeks. The fluctuating nature of the flow explains why elevated methane concentrations were measured in tidal estuaries during low tide (Middelburg et al. 1996).

The methane released from the Janssand could be from fossil sources, from remaining peat layers, or from recently fixed biomass. If it originates from fossil sources, the biomass would be formed millions of years ago and have lost its ${ }^{14} \mathrm{C}$ signal. If it originates from buried peat layers, the biomass would have formed before the peats were buried during the postglacial sea-level rise 5,000 to $20,000 \mathrm{yr}$ ago. If the methane is formed from recent biomass it could carry the so-called bomb signal. Indeed, the ${ }^{14} \mathrm{C}$ content of the $\mathrm{CH}_{4}$ escaping at the low-water line was $25 \%$ above the natural level prior to the detonations of the hydrogen bombs in the atmosphere in the early 1960s. The time when the carbon was originally fixed can be constrained by the time window where the ${ }^{14} \mathrm{C}$ ratio in atmospheric $\mathrm{CO}_{2}$ was at least as high as in the $\mathrm{CH}_{4}$ flowing out of Janssand, namely, between 1955 and 1987 (Manning et al. 1990; Levin et al. 2003). Thus carbon in the methane that escapes from Janssand is fixed from DIC obtained from the atmosphere only 20 to $50 \mathrm{yr}$ ago.

The dissolved inorganic carbon in the seeping fluids is dominated by $\mathrm{CO}_{2}$ from organic matter oxidized in the sand flat, since its DIC concentration of $20 \mathrm{mmol} \mathrm{L}^{-1}$ is about 10 times above that of seawater. The origin as degradation product from marine organic matter, and not from methane, is confirmed by the $\delta^{13} \mathrm{C}$ of -16 . Peat and other fossil organics can be excluded as the source for both the methane and the DIC based on their ${ }^{14} \mathrm{C}$ content. The ${ }^{14} \mathrm{C}$ signature of the $\mathrm{CO}_{2}$ was identical to the methane; thus both carbon pools stem from the degradation of the same organic carbon. The time window where ${ }^{14} \mathrm{C}$ predicts the methane carbon to be fixed overlaps with the 3-40 yr residence time of pore water calculated from the hydrological model. The best agreement is achieved when the lowest measured permeability is assumed, probably because the high permeability is only associated with the very surface.

The flow calculated from the lowest measured permeability can be considered the minimum estimate of flow in the flat. This calculated discharge rate near the low-water line $\left(\sim 0.5 \mathrm{~L} \mathrm{~m}^{-2} \mathrm{~d}^{-1}\right)$ is at the lower range of the discharge rates of 1-25 $\mathrm{L} \mathrm{m}^{-2} \mathrm{~d}^{-1}$ measured previously (Billerbeck et al. 2006a). The former study integrated flow over the entire slope including rapid shallow flow, whereas we only consider the methane-rich water that travels slower and deeper below the flat. Half a liter of methane-saturated water per square meter per day delivers $0.65 \mathrm{mmol}$ methane to the estuary per square meter per day. On Janssand the seeps comprise on the order of $2 \%$ of the surface area, so the seeps only leek about $0.013 \mathrm{mmol} \mathrm{C} \mathrm{m}^{-2} \mathrm{~d}^{-1}$ averaged over the entire sand flat. This is at least three orders of magnitude below the estimated rates of primary production and mineralization in the Wadden Sea (Asmus et al. 1998; van Beusekom et al. 1999; Philippart et al. 2007). This rough calculation suggests that methane seepage is of limited importance for the carbon cycle in intertidal flats. But it is probably very important for the coastal methane budget. The flux of methane from the estuary waters to the atmosphere of $0.13 \mathrm{mmol} \mathrm{m} \mathrm{m}^{-2} \mathrm{~d}^{-1}$ (Middelburg et al. 2002) can be explained by seepage from flats in areas with $1 \mathrm{~m}$ of seeping waterline per $50-500 \mathrm{~m}^{2}$ of water surface. This is a plausible ratio; thus it is likely that seeping intertidal sands are the source driving the methane efflux from tidal European estuaries calculated by Middelburg et al. (2002). It was estimated that estuaries contribute $9 \%$ of the total marine methane flux to the atmosphere (Middelburg et al. 2000). This estimate did not include the export of methane from estuaries to the open sea and transport to the atmosphere by ebullition; thus methane efflux from tidal estuaries with permeable sands might be higher than previously thought.

The source of organic material that fuels methanogenesis in the sand flats of the Wadden Sea is not obvious. In muddy coastal sediments methane is formed by slow degradation of a large pool of refractory organic matter that is continuously being buried by sedimentation. The methane is formed over often hundreds of meters of sediment column and diffuses toward the surface. A similar deep source cannot explain the methane in the seeps because of the low accumulation rate of sediment in the Wadden Sea, the low content of organic carbon, and the presence of bomb-derived ${ }^{14} \mathrm{C}$ in the methane. Thus relatively young material must undergo methanogenesis somewhere along the pore-water flow paths shown in Fig. 7. Seawater contains stoichiometrically less electron donor (C organic) than oxygen. The source therefore cannot be the water column directly without a preconcentration of organic matter in the top sediment, for example, by filtration due to the skin flow (Huettel and Rusch 2000; Rusch and Huettel 2000). However, benthic photosynthesis is increasingly recognized as an important source of organic carbon for intertidal and subtidal sand flats (MacIntyre et al. 1996; Middelburg et al. 2000; Cook and Røy 2006), and the ${ }^{14} \mathrm{C}$ content of the DIC and the methane from the seeps points to benthic photosynthesis as the carbon source. The ${ }^{14} \mathrm{C}$ content of DIC and methane in the seeps is higher than the North Sea concentration ever was (Erlenkeuser 1976; Nydal et al. 1980, 1984). This suggests that the atmosphere must have been an important source of carbon for the primary production eventually filling the methane pool. 
Thus, most photosynthesis must have occurred during low tide by benthic algae, probably cyanobacteria and diatoms. Whatever the source of the ${ }^{14} \mathrm{C}$ in the methane was, the organic material for its production was certainly fixed at the surface after 1955 .

The upper $120 \mathrm{~cm}$ of the central sand flat is methane free and contains seawater concentrations of sulfate; thus methane formation occurs deeper in the flats. The stoichiometry of organic carbon oxidation by sulfate reduction is $2 \mathrm{C}: 1 \mathrm{SO}_{4}^{2-}\left(2 \mathrm{CH}_{2} \mathrm{O}+\mathrm{SO}_{4}^{2-} \rightarrow 2 \mathrm{CO}_{2}+\right.$ $\mathrm{S}^{2-}+2 \mathrm{H}_{2} \mathrm{O}$ ). Since seawater contains ca. $28 \mathrm{mmol} \mathrm{L}^{-1}$ sulfate, at least $56 \mathrm{mmol} \mathrm{L}^{-1}$ of organic carbon is needed to deplete sulfate. The dissolved organic carbon in the pore water is less than $0.06 \mathrm{mmol} \mathrm{C} \mathrm{L}^{-1}$; thus the organic carbon for sulfate depletion in the anoxic sediments must be supplied from hydrolysis of organic particulates. The organic carbon content of the intertidal sands in the Wadden Sea is on the order of $1 \mathrm{~g} \mathrm{C}$ organic per kilogram of dry sediment, or ca. $500 \mathrm{mmol} \mathrm{C}$ organic per liter pore water. Burial of this amount of electron donor is more than sufficient for sulfate depletion and considerable methanogenesis if it is biodegradable within a few decennia. The question is how the organic material is transported from the sediment surface deep into the seabed in less than $40 \mathrm{yr}$. One possibility is continuous transport with the deep porewater flow, in the form of colloids, viruses, or small bacteria. An alternative explanation is batch-wise burial of organic rich surface sediment. A batch of surface sediment could be deposited in a meter-thick layer during a strong storm and form a reservoir of methane for a seep. Also, other mechanisms could be plausible, and the topic should be studied further, for example, by determining the ${ }^{14} \mathrm{C}$ distribution of methane and DIC in the sand flat.

The seeps on the slopes of Janssand are sulfidic, depleted in sulfate, and saturated with methane. The emerging concept for biogeochemistry of intertidal flats is that organics are entrained deep in the sand flats. A deep unidirectional pore-water flow follows a curved path toward the low-water line. As a result the biogeochemical conditions become highly structured in two dimensions, forming a habitat for a much wider diversity of microbial processes than previously thought. Organic matter that enters the flat is subjected along this trajectory to degradation, first aerobically, then by sulfate reduction, and finally by methanogenesis. At the end, when all microbial degradation processes have run their course, microbial activity is reduced to low levels, possibly resembling the deep biosphere (Wilms et al. 2006). Owing to the warped geometry, the oldest parts is at the surface near the low-water line.

Whereas it was recently reported that permeable sands are efficient bioreactors for aerobic degradation of organic matter (D'Andrea et al. 2002; de Beer et al. 2004), the deep body circulation can locally lead to intense anaerobic microbial processes in tidal flats and an outflow of reduced substances. Normally in sediments, products of anaerobic degradation, such as sulfide or methane, are reoxidized in the sediments with eventually oxygen as electron acceptor. At the seepage site, the outflow of pore water prevents diffusive penetration of electron acceptors such as oxygen and sulfate that can oxidize the reduced products of anaerobic degrada- tion (de Beer et al. 2006). The tidal flats therefore emit methane to the surface water and atmosphere in substantial amounts. The stability and structured transport phenomena, as well as their contribution to the methane budget, make permeable intertidal sand flats highly interesting for biogeochemical and for microbial diversity studies.

\section{References}

Asmus, R., M. H. Jensen, D. Murphy, and R. Doerffer. 1998. Primary production of micro- phytobenthos, phytoplankton, and annual biomass yield of macro-phytobenthos in the Sylt-Rømø Wadden Sea, p. 367-392. In C. Gätje and K. Reise [eds.], Ecosystem Wadden Sea: Exchange, transport, and turnover. Springer Verlag. [In German.]

Billerbeck, M., U. Werner, K. Bosselman, E. Walpersdorf, AND M. Huettel. 2006a. Nutrient release from an exposed intertidal sand flat. Mar. Ecol. Prog. Ser. 316: 35-51.

L. Polerecky, E. Walpersdorf, D. De Beer, And M. Huettel. 2006 b. Surficial and deep porewater circulation governs spatial and temporal scales of nutrient recycling in intertidal sand flat sediments. Mar. Ecol. Prog. Ser. 326: $61-76$.

Boetius, A., AND others. 2000. A marine microbial consortium apparently mediating anaerobic oxidation of methane. Nature 407: 623-626.

Cardenas, M. B., And J. L. Wilson. 2006. The influence of ambient groundwater discharge on exchange zones induced by current-bedform interactions. J. Hydrol. (1-2): 103-109.

Cook, P. L. M., AND H. Røy. 2006. Advective relief of $\mathrm{CO}_{2}$ limitation in microphytobenthos in highly productive sandy sediments. Limnol. Oceanogr. 51: 1594-1601.

D'Andrea, A. F., R. C. Aller, and G. R. Lopez. 2002. Organic matter flux and reactivity on a South Carolina sandflat: The impacts of porewater advection and macrobiological structures. Limnol. Oceanogr. 47: 1056-1070.

De BeEr, D., AND others. 2004. Transport and mineralization rates in North Sea sandy intertidal sediments (Sylt-Rømø Basin, Waddensea). Limnol. Oceanogr. 50: 113-127.

- AND OTHERS. 2006. In situ fluxes and zonation of microbial activity in surface sediments of the Håkon Mosby Mud Volcano. Limnol. Oceanogr. 51: 1315-1331.

Elvert, M., E. C. Hopmans, T. Treude, A. Boetius, and E. SuEss. 2005. Spatial variations of methanotrophic consortia at cold methane seeps: Implications from a high-resolution molecular and isotopic approach. Geobiology 3: 195-209.

ERlenkeuser, H. $1976 .{ }^{14} \mathrm{C}$ and ${ }^{13} \mathrm{C}$ isotope concentration in modern marine mussels from sedimentary habitats. Naturwissenschaften 63: 338.

Gardner, L. R., AND A. M. Wilson. 2006. Comparison of four numerical models for simulating seepage from salt marsh sediments. Estuar. Coast. Shelf. Sci. 69: 427-437.

Huettel, M., AND A. Rusch. 2000. Transport and degradation of phytoplankton in permeable sediments. Limnol. Oceanogr. 45: 534-549.

Jahnke, R. A., C. R. Alexander, and J. E. Kostka. 2003. Advective pore water input of nutrients to the Satilla River Estuary, Georgia, USA. Estuar. Coast. Shelf Sci. 56: 641-653.

Jørgensen, B. B., A. Weber, AND J. Zopfi. 2001. Sulfate reduction and anaerobic methane oxidation in Black Sea sediments. Deep-Sea Res. I 48: 2097-2120.

Levin, I., B. Kromer, M. Schmidt, and H. Sartorius. 2003. A novel approach for independent budgeting of fossil fuel $\mathrm{CO}_{2}$ over Europe by ${ }^{14} \mathrm{CO}_{2}$ observations. Geophys. Res. Lett. 30: 2194. 
Lotze, H. K. 2005. Radical changes in the Wadden Sea fauna and flora over the last 2000 years. Helgol. Mar. Res. 59: 71-83.

Macintyre, H. L., R. J. Geider, and D. C. Miller. 1996. Microphytobenthos: The ecological role of the secret garden of unvegetated, shallow-water marine habitats. 1. Distribution, abundance and primary production. Estuaries 19: 186-201.

Manning, M. R., D. C. Lowe, W. H. Melhuish, R. J. Sparks, G. Wallace, C. A. M. Brenninkmeijer, and R. C. McGill. 1990. The use of radiocarbon measurements in atmospheric studies. Radiocarbon 32: 37-58.

Martens, C. S., And J. V. Klump. 1980. Biogeochemical cycling in an organic-rich coastal marine basin. I. Methane sedimentwater exchange processes. Geochim. Cosmochim. Acta 44: 471-490.

Middelburg, J. J., G. Klaver, J. Nieuwenhuize, A. Wielemaker, W. de Haas, T. Vlug, and J. F. W. Avan der Nat. 1996. Organic matter mineralization in intertidal sediments along an estuarine gradient. Mar. Ecol. Prog. Ser. 132: 157-168.

- AND OTHERS. 2000. The fate of intertidal microphytobenthos carbon: An in situ ${ }^{13} \mathrm{C}$ labeling study. Limnol. Oceanogr. 45: 1224-1234.

, AND OTHERS. 2002. Methane distribution in European tidal estuaries. Biogeochemistry 59: 95-119.

Nielsen, P. 1990. Tidal dynamics of the water table in beaches. Water Resour. Res. 26: 2127-2134.

Nydal, R., S. Gulliksen, K. Lovseth, and F. H. Skogseth. 1984. Bomb ${ }^{14} \mathrm{C}$ in the ocean surface $1966-1981$. Radiocarbon 26: 7-45.

, K. Lovseth, and F. H. Skogseth. 1980. Transfer of bomb ${ }^{14} \mathrm{C}$ to the ocean surface. Radiocarbon 22: 626-635.

Peterson, B. J., And B. Fry. 1987. Stable isotopes in ecosystem studies. Annu. Rev. Ecol. Syst. 18: 293-320.

Philippart, C. J. M., AND OTHERs. 2007. Impacts of nutrient reduction on coastal communities. Ecosystems 10: 95-118.

Precht, E., And M. Huettel. 2003. Advective pore water exchange driven by surface gravity waves and its ecological implications. Limnol. Oceanogr. 48: 1674-1684.

Reeburgh, W. S. 1983. Rates of biogeochemical processes in anoxic sediments. Annu. Rev. Earth Planet Sci. 11: 269-298.
Riedl, R. J., N. Huang, and R. Machan. 1972. The subtidal pump: A mechanism of interstitial water exchange by wave action. Mar. Biol. 13: 210-221.

Rusch, A., And M. Huettel. 2000. Advective particle transport into permeable sediments - evidence from experiments in an intertidal sandflat. Limnol. Oceanogr. 45: 525-533.

RUTGERS VAN DER LOEFF, M. M. 1980. Time variation in interstitial nutrient concentrations at an exposed subtidal station in the Dutch Wadden Sea. Neth. J. Sea Res. 14: 123-143.

Stuiver, M., And H. A. Polach. 1977. Reporting of ${ }^{14} \mathrm{C}$ datadiscussion. Radiocarbon 19: 355-363.

Thibodeaux, L. J., and J. Boyle D. 1987. Bedform-generated convective-transport in bottom sediment. Nature 325: 341-343.

Treude, T., M. Krüger, A. Boetius, And B. B. Jørgensen. 2005. Environmental control on anaerobic oxidation of methane in the gassy sediments of Eckenfoerde Bay (German Baltic). Limnol. Oceanogr. 50: 1771-1786.

van Beusekom, J. E. E. 2005. A historic perspective on Wadden Sea eutrophication. Helgol. Mar. Res. 59: 45-54.

- , U. H. Brockmann, K. J. Hesse, W. Hickel, K. Porema, and U. Tillmann. 1999. The importance of sediments in the transformation and turnover of nutrients and organic matter in the Waddensea and German Bight. Dtsch. Hydrogr. Z. 51: 245-266.

Webster, I., Hancock, G., and Murray, A. 1994. Use of radium isotopes to examine pore-water exchanges in an estuary. Limnol. Oceanogr. 39: 1917-1927.

Werner, U. 2005. Microbial activity and transport processes in near-shore, permeable sediments. Ph.D. thesis, Univ. Bremen.

Wilms, R., B. Kopke, H. Sass, T. S. Chang, H. Cypionka, and B. ENGELEN. 2006. Deep biosphere-related bacteria within the subsurface of tidal flat sediments. Environ. Microbiol. 8: 709-719.

Received: 24 April 2007

Accepted: 10 December 2007

Amended: 21 February 2008 